\title{
Mengidentifikasi Gesture Matematis Siswa dalam Memecahkan Soal Geometri
}

\author{
Mega Sagita ${ }^{1}$, Benny Hendriana ${ }^{2}$ \\ ${ }^{1,2}$ Pendidikan Matematika, Fakultas Keguruan dan Ilmu Pendidikan, Universitas Muhammadiyah Prof. Dr. HAMKA \\ Jl. Tanah Merdeka No 20, Jakarta Timur, Indonesia \\ benny_hendriana@uhamka.ac.id
}

\begin{abstract}
Abstrak
In learning mathematics students often experience difficulties especially in solving geometry problems. This difficulty can be helped by the use of gestures. Gesture acts as a facilitator in learning mathematics especially geometry material. This study aims to identify the mathematical gestures used by students when solving geometric problems based on the Alibali and Nathan classifications that modify the McNeill classification. This research method is a qualitative approach with descriptive methods. Subjects in this study amounted to 5 people consisting of various levels. In this study, the data collection techniques used were observation, tests, interviews, and documentation. Then the data were analyzed using descriptive methods to obtain results. Based on this study, various kinds of gestures appeared to the five students while solving the given geometry problems. A total of 235 gestures were carried out by students consisting of 117 representational gestures with a percentage of $50 \%, 75$ gestures pointing with a percentage of $32 \%$, and 43 times writing gestures with a percentage of $18 \%$. Thus, gesture representation is often carried out by students in solving geometric problems.
\end{abstract}

Keywords: gesture, problem solving, geometry

\begin{abstract}
Abstrak
Dalam pembelajaran matematika siswa kerap kali mengalami kesulitan terutama dalam menyelesaikan masalah geometri. Kesulitan ini dapat dibantu dengan penggunaan gesture. Gesture bertindak sebagai fasilitator dalam pembelajaran matematika khususnya materi geometri. Penelitian ini bertujuan untuk mengidentifikasi gesture matematis yang digunakan oleh siswa pada saat memecahkan masalah geometri dengan berdasarkan klasifikasi Alibali dan Nathan yang memodifikasi dari klasifikasi McNeill. Metode penelitian ini merupakan pendekatan kualitatif dengan metode deskriptif. Subjek dalam penelitian ini berjumlah 5 orang yang terdiri dari berbagai macam jenjang. Pada penelitian ini teknik pengumpulan data yang digunakan yaitu observasi, tes, wawancara, dan dokumentasi. Kemudian data tersebut dianalisis dengan menggunakan metode deskriptif untuk mendapatkan hasil. Berdasarkan penelitian ini, berbagai macam gesture muncul pada kelima siswa selama menyelesaikan masalah geometri yang diberikan. Keseluruhan sebanyak 235 kali gesture dilakukan oleh siswa yang terdiri dari 117 kali gesture representasi dengan persentase 50\%, 75 kali gesture menunjuk dengan persentase 32\%, dan 43 kali gesture menulis dengan persentase $18 \%$. Dengan demikian gesture representasi sering dilakukan oleh siswa dalam memecahkan masalah geometri.
\end{abstract}

Kata kunci: gesture, memecahkan masalah, geometri

Copyright (c) 2021 Mega Sagita, Benny Hendriana

$\square$ Corresponding author: Benny Hendriana

Email Address: benny_hendriana@uhamka.ac.id (Jl. Tanah Merdeka No 20, Jakarta Timur)

Received 22 March 2021, Accepted 09 April 2021, Published 12 April 2021

\section{PENDAHULUAN}

Pembelajaran matematika merupakan sebuah pengalaman belajar matematika yang disiapkan oleh guru kepada siswa untuk dapat menyelesaikan permasalahannya sendiri, guru hendaknya memberikan kesempatan kepada siswa untuk berusaha dan mencari pengalamannya sendiri tentang materi matematika yang sedang dipelajarinya (Winarso \& Dewi, 2017). Contoh permasalahan yang dapat diselesaikan berdasarkan pengalaman belajar matematika terutama materi geometri yaitu ketika siswa diberikan latihan soal berupa gabungan dari bangun ruang. Latihan soal ini hanya sedikit berbeda dengan contoh soal yang sudah dijelaskan sebelumnya, tetapi siswa masih mengalami kesulitan dalam 
menyelesaikan soal. Di dalam menyelesaikan permasalahan dibutuhkan sebuah metode keterampilan yang wajib dimiliki siswa untuk mendapatkan perkembangan belajar yang signifikan dalam pembelajaran matematika (Ahmad, Hasliana, Latif, \& Tasni, 2020; Munawwarah, Laili, \& Tohir, 2020; Yuliana \& Ratu, 2019) Salah satu implementasi pembelajaran matematika yang efektif yaitu menyertakan siswa dalam melakukan afiliasi di antara representasi metematis untuk pemahaman secara intensif mengenai ide matematika dan berbagai langkah untuk pemecahan masalah (Hendriana, Waluya, Rochmad, \& Mulyono, 2019; Murtiyasa, 2015). Di antara materi matematika yang ada, materi geometri yang menjadi pokok materi matematika dalam penelitian ini.

Geometri itu sendiri merupakan ilmu yang berkaitan erat dengan materi lain dalam matematika dan sering diperlukan dalam kehidupan sehari-hari. Dalam bidang yang lain materi geometri memiliki kesempatan yang besar untuk dimengerti siswa, sebab materi geometri itu sendiri berkaitan dengan pengalaman siswa dan merupakan cara yang paling efektif untuk mengetahui kesulitan siswa (Yuliana \& Ratu, 2019). Menurut (Sholihah \& Afriansyah, 2018) manfaat pembelajaran geometri yaitu supaya siswa mendapatkan rasa percaya diri tentang kemampuan matematikanya, membentuk pemecah masalah yang baik, mampu berkomunikasi secara matematis, dan mampu bernalar secara matematis. Pokok bahasan geometri ini bukan merupakan pokok bahasan yang asing bagi siswa. Materi ini sering kita ditemukan pada kehidupan sehari-hari, seperti pada ruangan, garis dan lain-lain. Namun, kenyataannya masih banyak siswa yang mengalami kesulitan pada matematika termasuk materi geometri (Masita, Irawan, \& Sisworo, 2016).

Kesulitan siswa bisa terjadi karena kurangnya pemahaman mengenai geometri seperti konsep bangun datar, bangun ruang, sudut, dan lain-lain, kurangnya keterampilan dalam menggunakan ide-ide untuk pemecahan masalah, serta situasi dan kondisi kelas yang kurang kondusif (Listanti, Mampouw, Kristen, \& Wacana, 2020). Untuk mengatasi kesulitan belajar dan memperbaiki kesalahan pada saat pembelajaran geometri, pendidik wajib menerapkan pendekatan pembelajaran yang sesuai pada siswa. Hal ini sejalan dengan penelitian (Zainatu \& Aldila, 2017) yang menyatakan bahwa untuk mengatasi kesulitan belajar terutama di bidang geometri, guru harus menggunakan berbagai pendekatan pembelajaran. Pendekatan pembelajaran yang dilaksanakan pendidik dapat melalui gerakan-gerakan pada saat menjelaskan materi dikelas. Hal ini karena, siswa selalu mencontoh perbuatan pendidik dan cara siswa menerima dan memberi informasi banyak melibatkan gerakan-gerakan yang tidak disengaja. Gerakan-gerakan tersebut disebut sebagai gesture.

Gesture merupakan tindakan lengan dan tangan yang tanpa disadari bersamaan dengan keluarnya ucapan (Achadiyah, 2017). Sedangkan (Masita et al., 2016) mendefinisikan gesture merupakan bentuk komunikasi yang diperlukan dapat menginterprestasikan pemikiran siswa yang ada kalanya sulit untuk diungkapkan dalam wujud tulisan. Selanjutnya (Damayanti, 2018) menyatakan bahwa gesture merupakan bentuk komunikasi non-verbal bersamaan dengan gerakan tubuh yang tampak mengkomunikasikan perintah tertentu, seperti pengganti bicara atau bersamaan dan sejalan dengan katakata. Menurut (Bower et al., 2020; Salle, 2020; Yuli \& Siswono, 2019) pemahaman siswa tentang ide- 
ide matematika dapat diidentifikasi melalui penjelasan lisan (ucapan) atau gerakan atau gerak tubuh mereka. Adapun menurut (Arifin \& Rahma, 2015) matematis adalah kemampuan untuk menggunakan angka secara efektif. Jadi dapat disimpulkan bahwa gesture matematis adalah gerakan yang tanpa disadari dilakukan oleh seseorang dengan menggerakkan tangan atau lengan bersamaan pada saat berbicara mengenai matematika. Dalam hal ini berkaitan dengan geometri.

Berdasarkan penelitian (Achadiyah, 2017) McNeill mengelompokkan gesture menjadi empat kelompok utama, yaitu gesture ikonik, deiktik, beat, dan metaforik. Alibali \& Nathan memvariasikan klasifikasi gesture yang dilakukan McNeill menjadi tiga kelompok, yaitu (1) gesture menunjuk (pointing gesture), (2) gesture representasi (representation gesture), dan (3) gesture menulis (writing gesture). Gesture menunjuk tidak lain ialah gesture deiktik pada pengelompokkan McNeill. Gesture representasi melingkupi gesture ikonik dan gesture metaforik.

Gesture representasi merupakan gerakan visual memberikan hubungan formal yang erat antara konten semantik dan penjelasan dengan menggambarkan objek atau kejadian yang konkret atau abstrak (Sulistyorini, Studi, \& Matematika, 2019). Dalam bidang geometri tanpa disadari kita sangat sering melakukan gesture representasional. penggunaan gesture ini misalnya ketika guru mensimulasikan gerakan pada perubahan kemiringan suatu garis. Guru juga dapat menggunakan gesture ini untuk menerjemahkan konsep sudut siku-siku dalam objek yang nyata. Dalam hal ini guru membentuk kedua telapak tangannya sedemikian sehingga menggambarkan suatu sudut siku-siku. Gerakan ini dapat mendukung siswa dalam menyelesaikan suatu masalah dengan melakukan bantuan pada tangan untuk membuat suatu garis (Sulistyorini et al., 2019).

Gesture menunjuk ini dihubungkan antara proses bicara dan sikap yang terkait dengan lingkungan fisik. Lingkungan fisik yang digunakan pada saat berbicara seringkali melibatkan ibu jari, jari telunjuk, dan terkadang memerlukan alat tulis seperti bolpoin (Yuli \& Siswono, 2019). Ketika pendidik menunjuk suatu objek sambil memberikan penjelasan, informasi yang disampaikan menjadi terhubung dengan objek yang ditunjuk. Misalnya ketika guru menjelaskan konsep dari suatu materi geometri, contoh bangun ruang, dan siswa ditanya mengenai struktur dari bangun ruang itu sendiri pasti tanpa sadar siswa menunjuk kearah gambar bangun ruang tersebut. Menurut (Achadiyah, 2017) gesture ini digunakan dalam bentuk mendapatkan ketertarikan bersama atau mempertahankan ketertarikan bersama pada bagian penting dalam soal dengan mendapatkan gagasan baru sampai pada penyelesaian.

Gesture menulis adalah integrasi dari gerakan tangan seperti yang dikatakan guru (Yuli \& Siswono, 2019). Menurut (Sulistyorini et al., 2019) tulisan yang dihasilkan berhubungan dengan penjelasan sama seperti gerakan tangan berhubungan dengan penjelasan. Gesture ini berperan dalam menekankan bagian dari penjelasan dan memberikan catatan-catatan untuk menjelaskan materi yang disampaikan pendidik. Gesture ini akan meninggalkan tanda, misalnya pada papan tulis atau lembar kerja siswa. Fungsi gesture ini yaitu menuliskan sesuatu yang sudah diketahui dalam pikirannya sebagai bentuk final, dapat mengkongkretkan dalam bentuk tulisan dari sesuatu yang sedang dihitung, dan 
mengarahkan proses berpikir dari mengetahui langkah sebelumnya saat menghitung ke langkah selanjutnya (Achadiyah, 2017).

Berdasarkan penjelasan di atas, penelitian ini bermaksud untuk mengetahui gesture apa saja yang dikerjakan siswa dalam memecahkan masalah geometri berdasarkan klasifikasi gesture yang dibuat Alibali dan Nathan.

\section{METODE}

Jenis penelitian ini memanfaatkan pendekatan kualitatif dengan metode deskriptif, sebab penelitian ini menunjukkan atau mengidentifikasi jenis gesture yang dilakukan siswa pada saat menyelesaikan persoalan geometri sehingga objek penelitian menjadi jelas. Penelitian dilakukan oleh lima orang dengan mengunjungi setiap rumah dari subjek penelitian yang diteliti. Walaupun penelitian dilakukan di kediaman subjek tapi tidak mengurangi keakuratan data. Penelitian pertama dilakukan di kediaman rumah subjek penelitian yaitu di Villa Gading Harapan Bekasi Utara. Selanjutnya penelitian kedua dilakukan oleh 3 siswa bertempat di Aren Jaya Bekasi Timur. Kemudian penelitian ketiga bertempat di Kaliabang Tengah Bekasi Utara. Penelitian dengan judul Mengidentifikasi Gesture Matematis Siswa dalam Memecahkan Soal Geometri dilakukan pada semester genap tahun ajaran 2020/2021. Penelitian dilaksanakan mulai tanggal 23 Januari 2021 sampai 13 Februari 2021.

Pada penelitian ini prosedur pengumpulan data yang digunakan yaitu observasi, tes, dan wawancara. Dalam penelitian ini observasi yang dipakai berupa foto dan video dilakukan selama pelaksanaan penelitian berlangsung ketika siswa berdiskusi memecahkan masalah matematika terutama materi geometri, digunakan untuk mengamati siswa dalam memecahkan masalah geometri sehingga peneliti berhasil mengidentifikasi gesture yang digunakan siswa. Teknik tes yang digunakan mencakup 6 soal uraian yang telah divalidasi oleh ahli dosen Pendidikan Matematika Universitas Muhammadiyah Prof. Dr. HAMKA. Tes ini harus dikerjakan oleh siswa dengan bertujuan untuk memunculkan variasi gesture pada siswa saat proses menyelesaikan masalah yang diberikan. Selanjutnya wawancara berisi pertanyaan dari peneliti dan jawaban dari narasumber. Wawancara dilakukan dengan mengacu pada pedoman wawacara yang sudah divalidasi oleh ahli dosen Pendidikan Matematika Universitas Muhammadiyah Prof. Dr. HAMKA. Hasil dari wawancara ini digunakan untuk memperoleh hasil dari uraian secara lengkap terkait gesture yang digunakan siswa pada saat menyelesaikan masalah geometri. Teknik analisis data dilaksanakan secara deskriptif, yaitu dengan menguraikan atau mendeskripsikan hasil tes dan wawancara siswa. Data yang direduksi adalah data hasil tes dan wawancara. Data yang telah dicatat dan ditelaah akan dikumpulkan, dipilah-pilah, dan diklasifikasikan sesuai dengan data yang diperlukan untuk memenuhi rumusan masalah dalam penelitian ini. Data yang telah diklasifikasikan sesuai kebutuhan selanjutnya disimpulkan untuk mendapatkan hasil dari penelitian ini.

\section{HASIL DAN DISKUSI}

Berdasarkan hasil data penelitian yang sudah dilakukan oleh 5 siswa terdapat sebanyak 235 
gesture yang digunakan dalam menyelesaikan masalah geometri, mencakup gesture representasi, gesture menunjuk, dan gesture menulis.

Tabel 1. Hasil Analisis Data

\begin{tabular}{|c|c|c|c|c|c|c|c|}
\hline Subjek & Siswa 1 & Siswa 2 & Siswa 3 & Siswa 4 & Siswa 5 & Jumlah & $\%$ \\
\hline Representasi & 36 & 32 & 12 & 14 & 23 & 117 & $50 \%$ \\
\hline Menunjuk & 25 & 15 & 6 & 13 & 16 & 75 & $32 \%$ \\
\hline Menulis & 7 & 15 & 6 & 9 & 6 & 43 & $18 \%$ \\
\hline
\end{tabular}

\section{Gesture Representasi}

Berdasarkan penelitian yang sudah dilakukan, gesture representasi banyak dilakukan oleh lima orang siswa ini. Implementasi dari gesture ini dapat dilakukan siswa dengan membuat suatu objek dari jari tangan dan dapat dilakukan dengan menggunakan bolpoin di udara. Penelitian ini sependapat dengan (Alibali \& Nathan, n.d.) menyatakan jika gesture representasi dapat dikerjakan dengan menggambarkan pokok bahasan secara nyata dan dapat dikerjakan di udara.

Ketika siswa menjelaskan konsep dari garis dan sudut ke peneliti, siswa melakukan gerakan tangan yaitu dengan cara mengangkat kedua jari telunjuknya seraya membentuk garis sejajar. Selain itu siswa juga menggunakan bantuan bolpoin dan pensil untuk menjelaskan konsep dari garis berpotongan. Hal lain juga tercermin ketika siswa menjelaskan konsep dari sudut. Salah satu siswa memberikan penjelasan dengan mengangkat tangan kiri lalu membentuk sudut siku-siku dengan jari telunjuk dan jempol.

Berdasarkan hasil rekaman video pada detik empat puluh lima sampai menit dua detik lima belas, salah satu penjelasan siswa pada soal nomor 1a yaitu menjelaskan konsep dari garis sejajar mencerminkan gesture representasi, karena siswa mengangkat kedua jari telunjuknya dengan mengibaratkan bahwa itu bentuk garis sejajar.

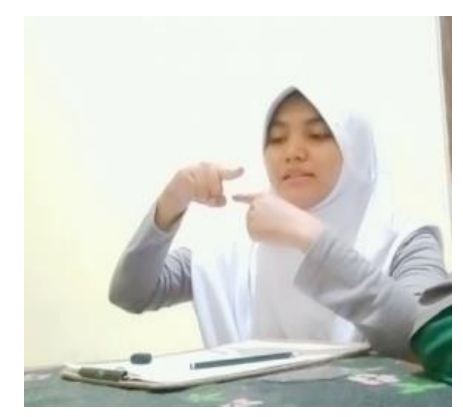

Gambar 1. Gesture Representasi

Peneliti : "Bagaimana kamu bisa memahami konsep dari garis dan sudut serta persegi panjang itu sendiri?"

Siswa : " "Garis itu ada 3, yang pertama garis sejajar tuh kaya gini sama panjang."

Representasi : Siswa mengangkat kedua jari telunjuknya dan membuat kedua jari telunjuknya sejajar atas dan bawah sama panjang. 
Dalam penelitian ini, siswa yang berinisial AL melakukan gerakan menggunakan bolpoin seraya menulis di udara. Hal ini tercermin ketika siswa menjelaskan rumus dari luas dan keliling persegi panjang. Siswa tersebut mengambil bolpoin dan selanjutnya menggerakan tangannya di udara seraya menulis di papan tulis.

Berdasarkan hasil rekaman video dalam menjelaskan konsep dari persegi panjang, AL mengangkat tangannya seraya membentuk huruf L untuk luas dan menggerakkan pulpen seraya menulis rumus dari luas dan keliling.

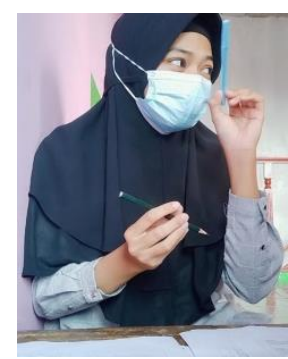

Gambar 2. Gesture Representasi

Peneliti : "Konsep persegi panjang. Luas dan kelilingnya apa?"

Siswa : "Rumusnya?"

Peneliti : "Iya."

Siswa : "Luasnya panjang kali lebar."

Peneliti : "Kalau kelilingnya?"

Siswa : "Dua dikali P + L."

Representasi : AL membayangkan kalau di depannya itu sebuah pulpen dan ia menggerakkan pulpen tersebut seraya menulis di papan.

Berdasarkan wawancara yang sudah dilakukan, dalam menggunakan gesture representasi siswa merasa terbantu dalam menjelaskan konsep dari garis dan sudut serta persegi panjang. Hal ini sependapat pada penelitian (Masita et al., 2016) yang mengungkapkan bahwa fungsi gesture representasi untuk menjelaskan pemikiran siswa tentang konsep matematika termasuk geometri melalui objek. Penelitian lain juga sependapat (Herdiman, Jayanti, Pertiwi, \& N, 2018) bahwa dalam pelaksanaan pembelajaran, siswa banyak melibatkan gerakan representasional karena gerakan ini memberikan manfaat bagi siswa dan guru. gesture representasional ini dapat meningkatkan wawasan dan kreativitas siswa dalam memecahkan masalah matematika. Hal ini karena dengan diterapkannya gesture representasional siswa dilatih untuk dapat membuat, membangun dan menerjemahkan suatu model dari konsep matematika kedalam penyelesaian masalah matematika.

Peneliti : "Pada saat kamu menjelaskan tadi, kamu menggunakan gerakan tangan untuk sudut dan garis. Nah gerakan seperti itu apakah bisa membantu kamu dalam menjelaskan ke temanmu?"

Siswa : : "Bisa banget kak."

Peneliti : "Berarti kalau misalkan saya sebagai temanmu menggunakan gerakan yang kamu 
lakukan tadi untuk menjelaskan ke kamu, kamu paham?”

Siswa : "Akan mempermudah kak."

Peneliti : :Seandainya teman kamu tidak menggunakan gerakan tangan seperti tadi yang kamu lakukan, kamu akan paham tidak?"

Siswa : "Lebih susah pahamnya kak."

Peneliti : "Berarti lebih mudah dengan menggunakan tangan itu ya?"

Siswa : "Iya."

Berdasarkan hasil penelitian gesture representasi banyak dilakukan siswa dalam menjelaskan konsep dari garis dan sudut. Terbukti dari hasil analisis data bahwa lima orang siswa melakukan gesture representasi sebanyak 117 kali dengan persentase 50\%. Hal ini sebanding dengan penelitian (Masita et al., 2016) bahwa berdasarkan hasil analisis data dan wawancara umumnya siswa melakukan gesture representasi dengan tujuan untuk menjelaskan objek yang berkaitan pada informasi yang tertera di soal.

\section{Gesture Menunjuk}

Dalam penelitian ini, gesture menunjuk yang digunakan siswa bervariasi, seperti menggunakan bolpoin, pensil, dan jari telunjuk. Gesture ini sering digunakan siswa dalam menjelaskan materi matematika termasuk geometri. Selain siswa, guru sebagai pendidik pun sering menggunakan gesture menunjuk. Berdasarkan penelitian (Sulistyorini et al., 2019) pendidik sering menggunakan gesture ini dalam memberikan penjelasan kepada siswa, karena dengan gesture ini informasi menjadi terhubung dengan objek yang ditunjuk.

Berdasarkan hasil video pada menit ke tujuh detik empat puluh tujuh, salah satu siswa melakukan gerakan menunjuk untuk menjelaskan garis bersilangan pada soal nomor 2 kepada peneliti.

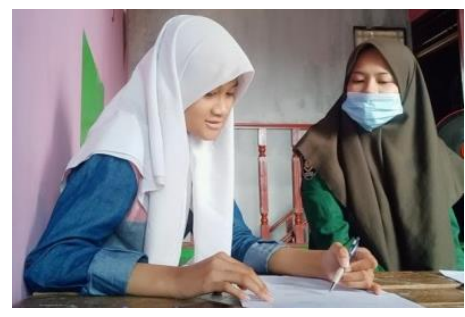

Gambar 3. Gesture Menunjuk

Siswa : "Nah kalau bersilangan dia kaya gini AB bersilangan dengan FG"

Menunjuk : Siswa menunjuk menggunakan pensil untuk memberitahu kalau soal nomer 3 cerminan dari garis bersilangan

Dalam penelitian ini gesture menunjuk ditujukan kepada peneliti. Menurut (Achadiyah, 2017) gesture menunjuk dapat ditujukan kepada diri sendiri dan orang lain. Tujuan siswa menggunakan gesture ini tidak lain untuk memberitahukan atau menjelaskan mengenai objek yang ingin dituju dengan melihat dari sebuah objek yang lain. Hal ini sependapat dengan penelitian yang diusulkan oleh (Elvierayani, 2016) bahwa gesture menunjuk sering digunakan pada proses pembelajaran karena siswa memeriksa untuk mendalami pemikirannya dengan jenis gesture yang dianggapnya mempermudah untuk memberikan informasi sesuai dengan yang dipikirkannya. Pemikiran ini juga mampu mendukung 
pengguna gesture untuk mengelola pikiran memori kerjanya selama berpikir untuk menyelesaikan masalah matematis terutama geometri dan melakukan penjelasan dengan lawan bicaranya.

Berdasarkan hasil penelitian ini ternyata gesture menunjuk sering dilakukan siswa dalam menjelaskan konsep garis dan sudut serta persegi panjang. Terbukti dari hasil analisis data dari 5 siswa ternyata sebanyak 75 kali dengan persentase $32 \%$ siswa melakukan gesture menunjuk.

\section{Gesture Menulis}

Gesture ini dilakukan ketika siswa menyelesaikan soal geometri. Dalam penelitian ini, semua siswa melakukan gesture menulis untuk menuliskan informasi, menggambar, dan berhitung dengan memberikan bekas permanen yang tertulis di kertas lembar jawaban siswa. Menurut (Sulistyorini et al., 2019) tulisan yang dihasilkan berhubungan dengan penjelasan sama seperti gerakan tangan berhubungan dengan penjelasan. Gesture ini berperan dalam menekankan bagian dari penjelasan dan memberikan catatan-catatan untuk menjelaskan materi yang disampaikan pendidik.

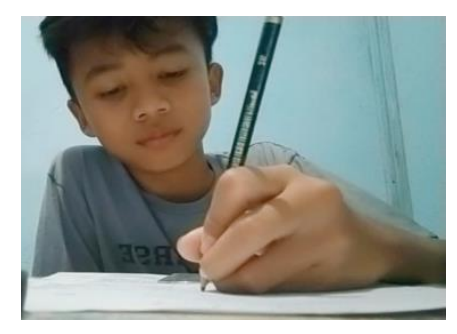

Gambar 4. Gesture Menulis

Berdasarkan gambar 4, salah satu siswa melakukan gesture menulis dalam hal menyelesaikan soal dan ketika menjelaskan soal nomor 6 tentang luas dan keliling persegi panjang kepada peneliti siswa ini pun tetap menggunakan gesture ini. Menurut (Achadiyah, 2017) fungsi kognisi gesture menulis yang digunakan siswa dalam penelitian ini dapat dikhususkan menjadi tiga, yang pertama menuliskan atau mengkongkretkan objek yang sudah ada ke dalam pikiran sebagai penjelasan akhir, misalnya menulis apa yang diketahui pada soal atau menulis kesimpulan. Lalu kedua mengkongkretkan objek yang masih dipikirkan, misalnya menulis hasil yang masih dihitung. Dan terakhir membimbing proses berpikir, misalnya memahami tahap selanjutnya setelah mengamati langkah sebelumnya saat menghitung. Berdasarkan hasil analisis data pada penelitian ini, sebanyak 43 kali dengan persentase $18 \%$ siswa melakukan gesture menulis.

Berdasarkan temuan penelitian yang dilakukan menunjukkan bahwa siswa yang diteliti sering melakukan gesture representasi dalam menyelesaikan masalah geometri. Dalam hal ini gesture representasi yang digunakan oleh siswa pada saat menjelaskan konsep dari garis dan sudut serta konsep persegi panjang. Penggambaran gesture representasi tersebut tercermin dari penggunaan jari telunjuk, jempol dan juga alat bantu seperti pulpen.

Gesture representasi dalam temuan ini menunjukkan untuk peneliti, yakni dilaksanakan setelah siswa memecahkan soal yang diberikan. Selanjutnya, siswa menguraikan konsep dan cara penyelesaian soal dari tiap nomer menggunakan jari telunjuk dan ibu jari. Tujuan siswa mengenakan jari telunjuk dan ibu jari dalam menguraikan konsep dan cara penyelesaian yaitu untuk membantu dan mempermudah 
siswa dalam memahami dari penjelasannya. Hal ini diketahui melalui wawancara yang dilakukan oleh lima siswa yang menyatakan bahwa dalam penggunaan jari telunjuk dan jempol dapat memudahkan siswa dalam memahami dan menjelaskan konsep garis dan sudut serta konsep persegi panjang ke peneliti.

\section{KESIMPULAN}

Berdasarkan penelitian yang sudah dilakukan, peneliti mendapatkan kesimpulan bahwa siswa dalam menyelesaikan soal geometri melakukan beberapa gesture. Gesture yang terdapat pada siswa dikelompokkan berdasarkan klasifikasi pendapat Alibali dan Nathan yang memodifikasi klasifikasi gesture yang dibuat oleh McNeill melputi gesture menunjuk, gesture representasi, dan gesture menulis.

Berdasarkan hasil observasi dan wawancara, total gesture yang dilakukan lima orang siswa adalah sebanyak 235 kali gesture. Dengan gesture representasi 117 kali dengan persentase 50\% dilakukan ketika siswa menjelaskan kepada peneliti mengenai konsep dari garis dan sudut serta penyelesaian soalnya menurut (Sundawan \& Nopriana, 2019) penggunaan gerakan representasi dalam pembelajaran matematika akan membantu masalah yang rumit menjadi sederhana dalam gagasan matematika yang konkret. Karena dalam penerapannya siswa menggunakan jari telunjuk, ibu jari, telapak tangan, bolpoin, dan pensil yang dapat membantunya dalam menjelaskan masalah geometri. Sedangkan siswa melakukan gesture menunjuk 75 kali dengan persentase 32\% dilakukan untuk menunjuk hasil dari penyelesaian soal. Menunjuk ini bisa tercermin dari objek atau bentuk di depan hadapan siswa. Kemudian gesture menulis dilakukan siswa sebanyak 43 kali dengan persentase 18\% ketika menyelesaikan masalah geometri yang diberikan. Gesture ini tercermin dari bukti coretan pada kertas yang ditulis siswa.

Jadi berdasarkan penjelasan di atas, peneliti merumuskan bahwa gesture yang sering dipakai siswa dalam menyelesaikan masalah geometri yaitu gesture representasi. Gesture representasi tanpa sadar sering dipakai siswa karena dapat membantu dalam menuangkan ide-ide dari penjelasan yang siswa sampaikan kepada peneliti.

\section{UCAPAN TERIMA KASIH}

Dengan selesainya penelitian ini, saya mengucapkan terima kasih kepada kedua orangtua, seluruh dosen program studi Pendidikan Matematika Universitas Muhammadiyah Prof. Dr. HAMKA dan semua pihak yang terlibat dalam penelitian ini, sehingga terlaksana dengan baik, lancar dan sukses.

\section{REFERENSI}

Achadiyah, N. L. (2017). Gestur Siswa Sekolah Menengah Pertama dalam Memecahkan Masalah Matematis secara Berkelompok, 3(1), 49-56.

Ahmad, H., Hasliana, L., Latif, A., \& Tasni, N. (2020). JURNAL CEMERLANG : Pengabdian pada 
Masyarakat PKM - PENINGKATAN KETERAMPILAN GURU MATEMATIKA SMK KABUPATEN MAJENE DALAM PENGGUNAAN GEOENZO SEBAGAI MEDIA PEMBELAJARAN MATEMATIKA JURNAL CEMERLANG: Pengabdian pada Masyarakat Guru Matematika SMK Kabupaten Ma, 3(1), 60-73.

Alibali, \& Nathan. (n.d.). Embodiment in Mathematics Teaching and Leaning: Evidence from Learner's and Teahcer's Gestures. The Journal of The Learning Sciences.

Arifin, A. L., \& Rahma, S. (2015). Building Personal Brand Equity. Gramedia Pustaka Utama.

Bower, C., Zimmermann, L., Verdine, B., Toub, T. S., Islam, S., Foster, L., ... Golinkoff, R. M. (2020). Piecing together the role of a spatial assembly intervention in preschoolers' spatial and mathematics learning: Influences of gesture, spatial language, and socioeconomic status. Developmental Psychology, 56(4), 686-698. http://doi.org/10.1037/dev0000899

Damayanti, N. W. (2018). Profil Gesture Mahasiswa dalam Representasi Diagonal Sisi dan Diagonal Ruang pada Kubus. EDU-MAT: Jurnal Pendidikan Matematika, 6(2), 171-177.

Elvierayani, R. R. (2016). Gesture Matematis Siswa dalam Menyelesaikan Masalah Fungsi. Jurnal Reforma, IV(1), 10-18.

Hendriana, B., Waluya, B., Rochmad, R., \& Mulyono, M. (2019). Kemampuan Komunikasi Matematis Siswa Berdasarkan Gaya Belajar Honey dan Mumford (Vol. 2, pp. 147-152).

Herdiman, I., Jayanti, K., Pertiwi, K. A., \& N, R. N. (2018). Kemampuan Representasi Matematis Siswa SMP pada Materi Kekongruenan dan Kesebangunan. Jurnal Elemen, 4(2), 216-229. http://doi.org/10.29408/jel.v4i2.539

Listanti, D. R., Mampouw, H. L., Kristen, U., \& Wacana, S. (2020). Profil Pemecahan Masalah Geometri Oleh Siswa SMP Ditinjau Dari Perbedaan Kemampuan Matematika. Jurnal Cendekia : Jurnal Pendidikan Matematika, 4(1), 365-379.

Masita, T. N., Irawan, E. B., \& Sisworo. (2016). Gesture Menunjuk dan Representasional Siswa Sesuai dengan Tahapan Berpikir Van Hiele. Jurnal Pendidikan: Teori, Penelitian, Dan Pengembangan, $1(2), 271$.

Munawwarah, M., Laili, N., \& Tohir, M. (2020). Keterampilan Berpikir Kritis Mahasiswa Dalam Memecahkan Masalah Matematika Berdasarkan Keterampilan Abad 21. Alifmatika: Jurnal Pendidikan Dan Pembelajaran Matematika, 2(1), 37-58. http://doi.org/10.35316/alifmatika.2020.v2i1.37-58 
Murtiyasa, B. (2015). Tantangan Pembelajaran Matematika Era Global, (3), 45.

Salle, A. (2020). Analyzing Self-Explanations in Mathematics: Gestures and Written Notes Do Matter. Frontiers in Psychology, 11(November), 1-17. http://doi.org/10.3389/fpsyg.2020.513758

Sholihah, S. Z., \& Afriansyah, E. A. (2018). Analisis Kesulitan Siswa dalam Proses Pemecahan Masalah Geometri Berdasarkan Tahapan Berpikir Van Hiele. Mosharafa: Jurnal Pendidikan Matematika, 6(2), 287-298. http://doi.org/10.31980/mosharafa.v6i2.317

Sulistyorini, Y., Studi, P., \& Matematika, P. (2019). Gestur dalam Pembelajaran Matematika Materi Irisan Kerucut dan Koordinat Polar. Jurnal Pendiidikan Matematika, 3(1), 1-9.

Sundawan, M. D., \& Nopriana, T. (2019). Guided-Discovery Learning, Representasi Matematis dan Konsep Diri Mahasiswa pada Materi Geometri. JNPM (Jurnal Nasional Pendidikan Matematika), 3(1), 123. http://doi.org/10.33603/jnpm.v3i1.1868

Winarso, W., \& Dewi, W. Y. (2017). Berpikir Kritis Siswa Ditinjau dari Gaya Kognitif Visualizer dan Verbalizer Dalam Menyelesaikan Masalah Geometri. Jurnal Tadris Matematika, 10(2), 117-133.

Yuli, T., \& Siswono, E. (2019). Students' gestures in understanding algebraic concepts, 12(24), 134. http://doi.org/10.20414/betajtm.v12i2.307

Yuliana, D., \& Ratu, N. (2019). Analisis Keterampilan Dasar Visual Geometri Siswa SMP Ditinjau Berdasarkan Level Berpikir Analisis Van Hiele. Jurnal Cendekia : Jurnal Pendidikan Matematika, 3(2), 536-549. http://doi.org/10.31004/cendekia.v3i2.135

Zainatu, S., \& Aldila, E. (2017). Analisis Kesulitan Siswa dalam Proses Pemecahan Masalah Geometri Berdasarkan Tahapan Berpikir Van Hiele. Mosharafa, 6(2), 290. 